Article

\title{
Wheat Grain Composition, Dough Rheology and Bread Quality as Affected by Nitrogen and Sulfur Fertilization and Seeding Density
}

\author{
Lorenzo Guerrini, Marco Napoli *, Marco Mancini, Piernicola Masella, Alessio Cappelli ${ }^{\circledR}$, \\ Alessandro Parenti and Simone Orlandini $(D$ \\ Department of Agriculture, Food, Environment and Forestry (DAGRI), University of Florence, \\ Piazzale delle Cascine 18, 50144 Firenze, Italy; lorenzo.guerrini@unifi.it (L.G.); marco.mancini@unifi.it (M.M.); \\ piernicola.masella@unifi.it (P.M.); alessio.cappelli@unifi.it (A.C.); alessandro.parenti@unifi.it (A.P.); \\ simone.orlandini@unifi.it (S.O.) \\ * Correspondence: marco.napoli@unifi.it; Tel.: +39-055-2755746
}

Received: 12 December 2019; Accepted: 3 February 2020; Published: 5 February 2020

check for updates

\begin{abstract}
Flour from old varieties are usually considered very weak flours, and thus difficult to use in breadmaking especially when processed as Italian "Tipo 2 " flour. Hence, the aim of our study was to understand if agronomic treatments can be used to improve flour processability and the quality of three old wheat varieties. An experimental strip-plot scheme was used: three old wheat varieties (Andriolo, Sieve, Verna), two seeding densities, three levels of nitrogen fertilization (N35, N80, and N135), and two levels of foliar sulfur fertilization. Analyzed parameters related to kernel composition, dough rheology and bread quality. Sulfur and nitrogen treatments significantly affected protein composition and dough alveograph strength, which increased by about $34 \%$ with nitrogen fertilization, and by about $14 \%$ with the sulfur treatment. However, only nitrogen fertilization affected bread characteristics. Crumb density significantly decreased from N35 to N135, while springiness and cohesiveness increased. On the other hand, sulfur did not improve breads. This highlight the importance of performing breadmaking tests in addition to the rheological determinations. The poor technological performance of old wheat flours can be improved with agronomical treatments designed to obtain higher-quality bread.
\end{abstract}

Keywords: old wheat varieties; sulfur fertilization; protein composition; Italian "Tipo 2" flour; baking quality

\section{Introduction}

Wheat cultivated before the 'green revolution' (up until the late 1960s) are currently called 'old wheats', while those registered later are called 'modern wheats' [1,2]. Since the 1970s, the cultivation of old wheats has been progressively abandoned, as they are less productive than modern wheats, with less protein production per hectare, and with a gluten composition characterized by less gliadin and glutenins [3]. The latter is one of the main problems affecting the old wheat varieties, being that wheat end-use is strongly related to the gluten matrix characteristics [4]. In fact, flour from old wheat varieties are reported being very weak flours and not suitable for the industrial baking especially when processed as Italian "Tipo 2" flours $[2,5,6]$. However, in recent years, old wheats have been re-introduced as a contributing to the safeguarding of germplasm and, consequently, biodiversity [7]. A micro-economy has developed around old wheats, allowing local producers to differentiate their products and increase their remuneration [8]. However, their poor breadmaking performance still remains the biggest obstacle to their popularity. 
Italian "Tipo 2" flour made from old varieties has usually poor rheological properties, resulting in a dough that is difficult to work [8]. The resulting breads are usually low volume with a dense crumb structure, two characteristics that are not appreciated by consumers [9]. Moreover, the Italian "Tipo 2" flours were found to result in dough with higher tenacity and lower extensibility than those refined [8]. Hence, several efforts have been made to improve their technological performance. For example, Parenti et al., (2013) [10] added a process control based on a twin arm mixer to find the optimal mixing time, Cappelli et al., (2018) [8] evaluated the amount of water required to optimize the compromise between $\mathrm{W}$ and $\mathrm{P} / \mathrm{L}$, while bread makers have developed several protocols aimed at improving the quality of the final product [2]. Furthermore, it has been established that also agronomical treatments can significantly affect kernel composition, dough rheology and, ultimately, bread quality. For example, Geleta et al. (2002) [11] observed decreasing the protein concentration in kernel as the seeding rate increased. Gooding et al. (2002) [12] and Zhang et al. (2016) [13] reported the nitrogen availability greatly influencing optimal plant densities for kernel yield and quality traits. Otteson et al. (2008) [14] found that increasing the nitrogen rate increased the protein concentration in kernel and bread loaf volume, while seeding rate did not significant affect both kernel quality baking quality. Salvagiotti et al. (2009) [15] found sulfur fertilization improving the nitrogen uptake rate before anthesis thus increasing the final kernel yield. Tea et al. (2005) [16] and Tea et al. (2007) [17] found that nitrogen and sulfur fertilization at anthesis stage increasing the kernel protein content and improving the gluten network, the dough strength, swelling, and extensibility. Tao et al. (2018) [18] found sulfur fertilization significantly increasing total protein and starch content in kernel, and increasing glutenin and gliadin content, and the ratio of glutenin to gliadin. According to the latter study, the addition of sulfur and nitrogen to the wheat could play an important role in final bread quality, but the idea has received little attention. Particularly, to the best of the authors knowledge, no work specifically focused on the nitrogen-sulfur interactions while performing breadmaking trials. Furthermore, no study evaluated the effects of seed density, nitrogen fertilization and sulfur addition on dough rheology and bread quality for old wheats. Hence, we tested the effect of three agronomical treatments on three old wheat varieties, namely Verna, Sieve and Andriolo.

\section{Material and Methods}

\subsection{Wheat Cultivation}

Field experiments were established in October 2016 under rainfed conditions at the Giuseppe Chiarion farm, located in Monteroni d'Arbia, about $20 \mathrm{~km}$ south-east of Siena, Tuscany, Italy $\left(43.2007^{\circ}\right.$ $\mathrm{N}, 11.4182^{\circ} \mathrm{E}, 160 \mathrm{~m}$ a.s.l.) [19]. Egyptian clover (Trifolium alexandrinum, L.) was the previous crop. The soil was silty clay loam, and the $0-0.3 \mathrm{~m}$ layer contained $11.4 \mathrm{~g} \mathrm{~kg}^{-1}$ total organic carbon, $1620 \mathrm{mg}$ $\mathrm{kg}^{-1}$ total nitrogen, $14.2 \mathrm{mg} \mathrm{kg}^{-1}$ available phosphorus, and $273 \mathrm{mg} \mathrm{kg}^{-1}$ potassium. A meteorological station was placed near the experimental field, and data on temperature and humidity were recorded. Three Italian old genotypes of common wheat (Triticum aestivum, L.) were studied, namely Andriolo, Sieve and Verna.

Thirty-six treatments were investigated. These involved combinations of three varieties of common wheat, two seeding rates (90 and $180 \mathrm{~kg}$ seed ha ${ }^{-1}$; D90 and D180 respectively), three nitrogen (N) fertilization levels (35, 80 and $135 \mathrm{~kg} \mathrm{~N} \mathrm{ha}^{-1} ; \mathrm{N} 35, \mathrm{~N} 80$ and N135 respectively), and two sulfur (S) fertilization treatments ( 0 and $6.4 \mathrm{~S} \mathrm{~kg} \mathrm{ha}^{-1}$; $\mathrm{S} 0$ and $\mathrm{S} 1$ respectively).

The experimental arrangement was a strip-plot design, with wheat cultivars arranged in vertical strips (main plots). N (nitrogen fertilization) was allocated to horizontal subplots, seeding density was applied to vertical sub-subplots, and S (sulfur fertilization) was applied vertically to sub-sub-subplots (Figure 1). 


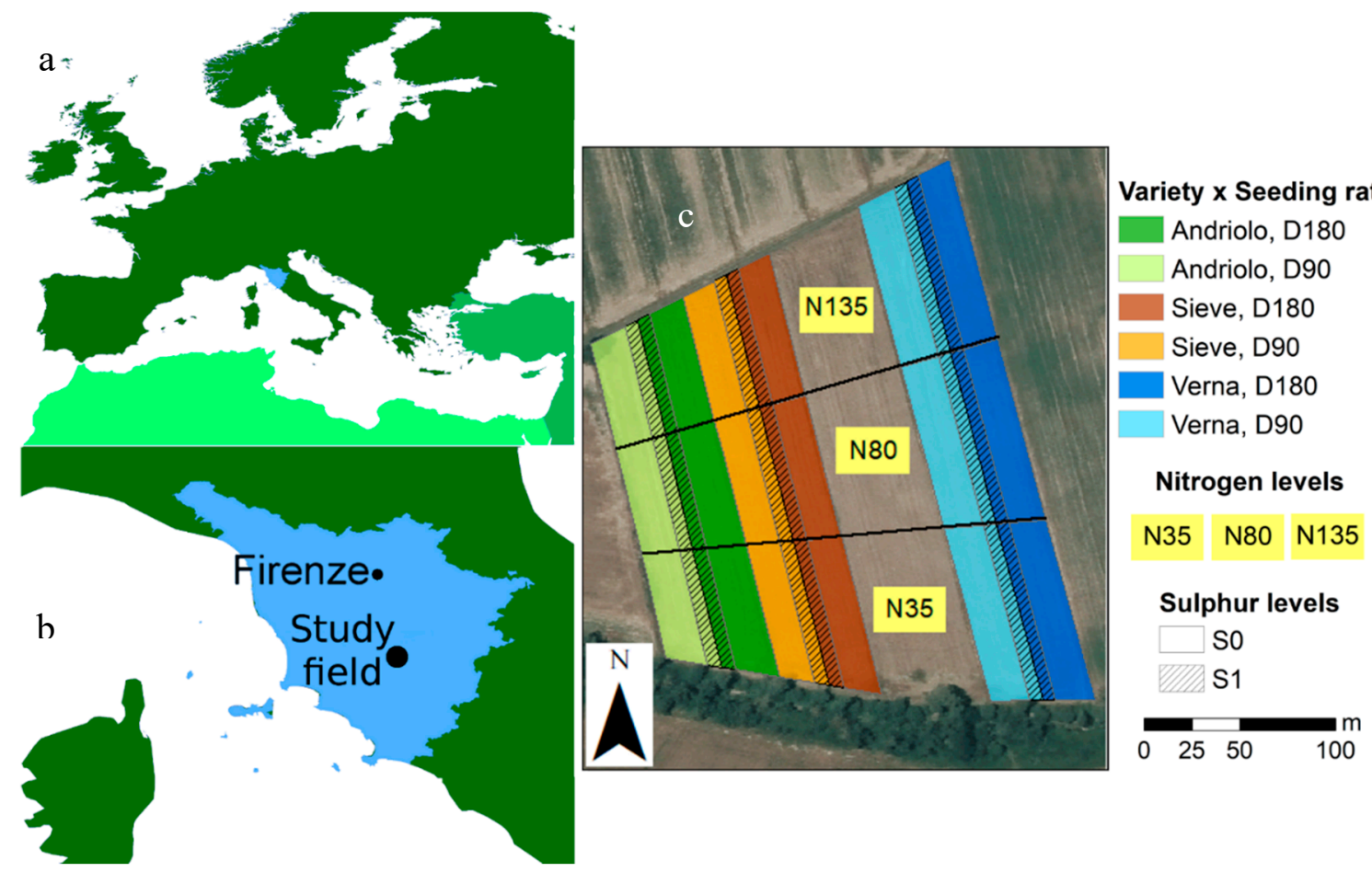

Figure 1. Maps of the study area. (a) Map of Tuscany within Europe. (b) Map of the Chianti region in Tuscany, and the location of the study field. (c) Layout of the study field. Seed densities levels D90 and D180 indicates 90 and $180 \mathrm{~kg}$ of seed ha ${ }^{-1}$, respectively. Nitrogen levels N35, N80 and N135 indicate 35, 80 and $135 \mathrm{~kg} \mathrm{~N} \mathrm{ha}^{-1}$, respectively. Sulfur levels, S0 and S1 indicate 0 and $6.4 \mathrm{~kg} \mathrm{~S} \mathrm{ha}^{-1}$, respectively. The area between the variety Sieve and Verna was cultivated with a 'modern' wheat variety (Triticum aestivum, L var. Bologna) with the same cultivation techniques of the 'old' ones (Bologna variety results were not used in this paper).

Seeds were sown on December 19,2016 . A total of $175 \mathrm{~kg} \mathrm{ha}^{-1}$ of triple superphosphate $\left(\mathrm{P}_{2} \mathrm{O}_{5}\right.$ : $46 \%$ ) was broadcast on treatments N35, N80, and N135. Nitrogen total dose was scheduled in three different applications: $20 \%$ by broadcasting urea ( $\mathrm{N}: 46 \%$ ) at seeding, $40 \%$ by spreading ammonium nitrate (N: $26 \%)$ at tillering, and $40 \%$ by spreading urea (N: $46 \%)$ at stem elongation.

The S1 treatment was performed at booting by spraying a wettable sulfur powder (Thiovit Jet 80 $\mathrm{WG}^{\circledR}$, Syngenta, Basel, Switzerland) at a rate of $8 \mathrm{~kg} \mathrm{ha}^{-1}\left(6.4 \mathrm{~kg} \mathrm{ha}^{-1}\right.$ of active ingredient). Although Thiovit is commonly used as a fungicide at a recommended rate of $8 \mathrm{~kg} \mathrm{ha}^{-1}$, we tested it as an alternative to sulfur fertilizers. At tillering, an herbicide treatment was performed by distributing Axial Pronto 60 (Syngenta, Basel, Switzerland) at a dose of $0.75 \mathrm{~L} \mathrm{ha}^{-1}\left(60 \mathrm{~g} \mathrm{~L}^{-1}\right.$ Pinoxaden and $15 \mathrm{~g}$ $\mathrm{L}^{-1}$ and Cloquintocet-mexyl) and Marox SX (Cheminova Agro Italia, Rome, Italy) at a rate of $0.75 \mathrm{~L}$ $\mathrm{ha}^{-1}$ (333 $\mathrm{g} \mathrm{L}^{-1}$ of thifensulfuron-methyl and $167 \mathrm{~g} \mathrm{~L}^{-1}$ of tribenuron-methyl). At booting, a fungicide treatment was performed by spraying Amistar Xtra (Syngenta, Basel, Switzerland) at a rate of $0.8 \mathrm{~L}$ ha $^{-1}$ (Azoxystrobin 18.2\% and Cyproconazole 7.3\%) and Sakura (Sumitomo Chemical Co., Tokyo, Japan) at a rate of $1.2 \mathrm{~L} \mathrm{ha}^{-1}$ (Bromuconazole $167 \mathrm{~g} \mathrm{~L}^{-1}$ and Tebuconazole pure $107 \mathrm{~g} \mathrm{~L}^{-1}$ ).

No noticeable crop damage was observed during the growing season due to weeds, insects, or disease. In particular, no fungal attacks were observed either on surfaces treated with sulfur, or on untreated surfaces. Harvesting was performed at wheat commercial maturity (kernel moisture lower than $13 \%$ ) on 10 July 2017. The three varieties reached the commercial maturity on the same time. For each treatment, three plant samples were randomly collected from an area measuring $0.5 \mathrm{~m}^{2}$. Wheat from each treatment was harvested separately using a combine-harvester equipped with Trimble GPS sensors, and yield monitoring sensors designed to measure and record information such as kernel flow 
and moisture, area covered and location. For each treatment, $5 \mathrm{~kg}$ of harvested wheat kernel were sampled for quality and technical analyses.

\subsection{Analysis of Kernel}

For each kernel sample, the following analyses were performed in triplicate. The hectoliter weight (HW; kg hL ${ }^{-1}$ ) and 1000 kernel weight (KW, g 1000-1 seeds) were determined according to ISO 7971-1 [20] and ISO 520 [21], respectively. Kernel samples were milled using a grinder with a $0.5 \mathrm{~mm}$ screen (Cyclotec 1093 lab mill, FOSS Tecator, Höganäs, Sweden) as reported in Zilic et al. (2011) [22]. Then, wholemeal flour samples (5 mg) were analyzed with a CHNS analyzer (CHN-S Flash E1112, Thermo-Finnigan LLC, San Jose, CA, USA) to determine total nitrogen and total carbon.

\subsection{Analysis of Proteins}

A modified Osborne fractionation [23] was performed to isolate the single protein fractions: water soluble (albumins), $0.5 \mathrm{M}$ sodium chloride soluble (globulins), 70\% ethanol soluble (gliadins), $0.1 \mathrm{M}$ acetic acid soluble (glutenin), and insoluble proteins. Two hundred grams of raw wheat kernel were milled using the previously described grinder with a $0.5 \mathrm{~mm}$ screen [22]. Then, the resulting wholemeal flour $(150 \mathrm{~g}$ ) was defatted using $600 \mathrm{~mL}$ of hexane and vortex for $90 \mathrm{~min}$. This suspension was centrifuged (10000 rpm, $10 \mathrm{~min}$ ) and extracts discarded. The defatted flour was air-dried under a hood at $20^{\circ} \mathrm{C}$ for $24 \mathrm{~h}$. Next, $100 \mathrm{~g}$ were sequentially extracted using four solvents (see below). Initially, flour was extracted with deionized water (400 mL) [24] for $30 \mathrm{~min}$, vortexing for $1 \mathrm{~min}$, every $10 \mathrm{~min}$. Then, the mixture was centrifuged for $5 \mathrm{~min}$ at $2000 \mathrm{rpm}$. The supernatant was recovered and stored. The extraction was repeated two more times over the resulting pellet with the same solvent; recovered supernatants were combined, designated as the albumin extract, and stored at $4{ }^{\circ} \mathrm{C}$ in the dark. The resulting pellet was extracted with $400 \mathrm{~mL} 0.5 \mathrm{~N} \mathrm{NaCl}$ solution [25] for $60 \mathrm{~min}$, vortexed for $2 \mathrm{~min}$, at $10 \mathrm{~min}$ intervals. Then the mixture was centrifuged at $3000 \mathrm{rpm}$ for $10 \mathrm{~min}$ and the supernatant recovered. This extraction was repeated twice and the supernatants were combined (globulin extract) and stored at $4{ }^{\circ} \mathrm{C}$ in the dark. The pellet was then extracted with $400 \mathrm{~mL} 70 \%$ ethanol solution [26] for $60 \mathrm{~min}$, vortexed for $1 \mathrm{~min}$, every $10 \mathrm{~min}$. Then, the mixture was centrifuged for $10 \mathrm{~min}$ at $3000 \mathrm{rpm}$, and the supernatant recovered. The procedure was repeated three times to remove all of the protein in this fraction, before the three supernatants were combined (gliadin extract) and stored at $4{ }^{\circ} \mathrm{C}$ in the dark. Finally, the centrifugate was extracted with $400 \mathrm{~mL}$ acetic acid $0.1 \mathrm{M}$ [27] for $90 \mathrm{~min}$, vortexed for $1 \mathrm{~min}$, every $10 \mathrm{~min}$ and then centrifuged for $5 \mathrm{~min}$ at $3000 \mathrm{rpm}$, to obtain the supernatant. Acid extraction was repeated three times before the supernatants were combined (glutenin extract) and stored at $4{ }^{\circ} \mathrm{C}$ in the dark. Gliadin was precipitated from its extract by adding acetone, following the procedure given in Tecson et al. (1971) [28]. Other proteins were precipitated by adjusting $\mathrm{pH}$ to $4.1,4.3$ and 4.8, for albumin, globulin and glutenin, following the procedure reported in Ju et al. (2001) [24]. The precipitate was oven-dried $\left(105^{\circ} \mathrm{C}, 5 \mathrm{~h}\right)$ and weighed. Remaining, insoluble protein was determined following the procedure given in Bean et al. (1998) [29]. Solvent residues were removed from the pellet resulting from acid extraction by mixing it with $10 \mathrm{~mL}$ of acetone, centrifuging (10000 rpm, $5 \mathrm{~min}$ ) and discarding the extracts. The pellet was crushed with a mortar and pestle, then oven-dried $\left(105^{\circ} \mathrm{C}, 5 \mathrm{~h}\right)$. Dried pellets were analyzed to determine total Kjeldahl nitrogen (TKN). The resulting TKN values were converted to insoluble protein by multiplying by 5.7 according to ICC Standard 167 (2000) [30]. Total protein was calculated by summing the weight of the five protein groups described above. Protein fractions were expressed as \% of total protein on dry weight basis.

\subsection{Analysis of Doughs}

The flours were sieved to reach the Italian "Tipo 2" law standard, since their ash content ranged from $0.80 \%$ to $0.95 \%$. Dough rheology was assessed with the Chopin alveograph according to ISO 27971 [31] procedures. Briefly, $250 \mathrm{~g}$ of flour was weighted and mixed in the alveograph chamber with a $\mathrm{NaCl}$ solution $(2.5 \% \mathrm{w} / \mathrm{w})$ for $8 \mathrm{~min}$. No yeasts were added. Then, dough was extruded and rested for 
$20 \mathrm{~min}$ before the measurement. Data are obtained with a Chopin alveograph, which can evaluate the rheological properties of doughs made from these flours. The alveograph measures several parameters, such as: $\mathrm{P}$, which refers to dough tenacity (i.e., resistance to deformation); L, which concerns dough extensibility (i.e., the maximum volume of air that a dough bubble is able to contain); $\mathrm{P} / \mathrm{L}$, the ratio between $P$ and $L$ values (i.e., the curve); $G$, the index of swelling, related to the volume of air required to break the dough bubble; and $\mathrm{W}$, which measures dough strength (i.e., the surface under the curve).

\subsection{Breadmaking Process}

To evaluate the effect of agronomical treatments, breads were prepared using the following recipe; $310 \mathrm{~g}$ of Italian "Tipo 2" flour was mixed with $180 \mathrm{~g}$ of water, and $9 \mathrm{~g}$ of $\mathrm{NaCl}$ was added. Mixing of ingredients ( $25 \mathrm{~min}$ at room temperature), dough formation, resting, leavening ( $1 \mathrm{~h}$ and $20 \mathrm{~min}$ at $40^{\circ} \mathrm{C}$ ) with $12 \mathrm{~g}$ of fresh brewer's yeast (Lievital, Trecasali, Italy), and baking $\left(55 \mathrm{~min}\right.$ at $180^{\circ} \mathrm{C}$ ) were all carried out with a bread machine (Pain dorè, Moulinex, Ecully, France) [32].

\subsection{Analysis of Breads}

The millet displacement method [33] was used to measure bread volume. Specific volume was determined as the ratio between bread total volume and bread weight. Crumb specific volume was determined by cutting 5-10 $\mathrm{g}$ of bread crumb and calculating the ratio between its volume measured with the standard millet displacement method and its weight. This method was adapted from [33] as reported in Cappelli et al. 2020 [34] and in Parenti et al. 2019 [32]. Crumb and crust moisture were measured by gravimetry at $105^{\circ} \mathrm{C}$ until constant weights were reached.

The Texture Profile Analysis (TPA) of bread samples was carried out by two-bite compression using a Texture Analyzer (TA-XT2, Stable Micro Systems, Godalming, Surrey, England), with a circular flat-plate probe (diameter of $25 \mathrm{~mm}$ ) according to the procedure described in Kim et al. (2017) [35]. Three slices of about $1 \mathrm{~cm}$ thickness were cut at the middle of each bread sample. Thus, for each sample, 3 measurement replicates were performed, and the median value was taken. Mechanical test conditions were as follows: $50 \%$ compression rate, $50 \mathrm{~N}$ of automatic trigger load, $10 \mathrm{~mm}$ of travel distance and $3 \mathrm{~mm} \mathrm{~s}^{-1}$ for pre-test, test and post-test speeds. Crumb hardness, cohesiveness, gumminess, chewiness and springiness were measured.

\subsection{Statistical Analysis}

A 3-way ANOVA was used to test the main effect of the three agronomical factors and their interactions. Significance was set at $p<0.05$. When the significance level was reached, a Tukey HSD post-hoc test was run. The inclusion of only one year means that we did not test the varieties, since with different pedo-climatic conditions the varieties response could be different. However, the varieties can still be considered semi-independent replications, which means that the main effects of the agronomical treatments are better defined than if this research had been done on only one variety. The software used was $\mathrm{R}$ version 3.6.0.

\section{Results and Discussion}

Our experimental design allowed us to evaluate the effect of the three treatments ( $\mathrm{N}$ fertilization, seed density, and $\mathrm{S}$ fertilization). The effect of the three agronomical treatments was evaluated in terms of kernel quality and, particularly, hectoliter weight, 1000 kernel weight, kernel C and N content, total proteins, and protein composition. Average production for Andriolo, Sieve and Verna varieties (Table 1) was 2925, 4204, and $2955 \mathrm{~kg} \mathrm{ha}^{-1}$, respectively. 
Table 1. Mean of kernel quality parameter results by nitrogen fertilization, sulfur fertilization, seed density, cultivar and first order interaction. The sig columns report the ANOVA results $\left({ }^{*}=0.05,{ }^{* *}=\right.$ $0.01,{ }^{* * *}=0.001, \mathrm{~ns}=$ not significant), while lowercase letters represent the Tukey HSD post hoc test results. RSE = residual standard error.

\begin{tabular}{|c|c|c|c|c|c|c|c|c|c|c|}
\hline \multirow[t]{2}{*}{ Source of Variation } & \multicolumn{2}{|c|}{$\begin{array}{c}\text { Kernel Yield } \\
\left(\mathrm{kg} \mathrm{ha}^{-1}\right)\end{array}$} & \multicolumn{2}{|c|}{$\begin{array}{l}\text { 1000-Kernel } \\
\text { Weight (g) }\end{array}$} & \multicolumn{2}{|c|}{$\begin{array}{l}\text { Hectoliter Weight } \\
\left(\mathrm{kg} \mathrm{hL}^{-1}\right)\end{array}$} & \multicolumn{2}{|c|}{$\begin{array}{c}\text { Total Nitrogen } \\
(\%)\end{array}$} & \multicolumn{2}{|c|}{$\begin{array}{c}\text { Total Carbon } \\
(\%)\end{array}$} \\
\hline & Average & sig & Average & sig & Average & sig & Average & sig & Average & sig \\
\hline \multicolumn{11}{|l|}{$\begin{array}{l}\text { Main effect } \\
\text { Cultivar }\end{array}$} \\
\hline Andriolo & 2925.43 & & 44.32 & & 71.83 & & 2.21 & & 45.8 & \\
\hline Sieve & 4203.85 & & 40.89 & & 74.05 & & 2.2 & & 45.51 & \\
\hline Verna & 2955.07 & & 37.46 & & 72.35 & & 2.28 & & 45.46 & \\
\hline Seeding density & & ns & & ** & & ns & & ns & & ns \\
\hline D90 & 3395.04 & $\mathrm{a}$ & 41.84 & $\mathrm{a}$ & 72.94 & a & 2.20 & a & 45.57 & $\mathrm{a}$ \\
\hline D180 & 3327.86 & $\mathrm{a}$ & 39.94 & $\mathrm{~b}$ & 72.54 & $\mathrm{a}$ & 2.26 & a & 45.61 & a \\
\hline Sulfur & & ns & & ns & & ns & & ns & & * \\
\hline S0 & 3357.21 & $\mathrm{a}$ & 41.51 & $\mathrm{a}$ & 72.58 & $\mathrm{a}$ & 2.16 & $\mathrm{a}$ & 45.85 & a \\
\hline S1 & 3366.16 & a & 40.27 & a & 72.89 & $\mathrm{a}$ & 2.3 & a & 45.33 & $\mathrm{~b}$ \\
\hline Nitrogen & & ** & & ns & & ns & & $* *$ & & ns \\
\hline N35 & 2667.66 & $\mathrm{~b}$ & 41.16 & $\mathrm{a}$ & 72.98 & $\mathrm{a}$ & 2.07 & $\mathrm{~b}$ & 45.45 & $\mathrm{a}$ \\
\hline N80 & 3107.08 & $\mathrm{~b}$ & 40.81 & a & 72.12 & a & 2.12 & $\mathrm{~b}$ & 45.71 & $\mathrm{a}$ \\
\hline N135 & 4309.6 & a & 40.7 & a & 73.12 & $\mathrm{a}$ & 2.49 & a & 45.61 & $\mathrm{a}$ \\
\hline RSE & 564.24 & & 1.84 & & 1.89 & & 0.24 & & 0.36 & \\
\hline \multicolumn{11}{|l|}{ Interactions } \\
\hline Nitrogen $\times$ Sulfur & & ns & & ns & & ns & & * & & ns \\
\hline $\begin{array}{c}\text { Nitrogen } \times \text { Seed } \\
\text { Density }\end{array}$ & & ns & & ns & & ns & & ns & & ns \\
\hline Sulfur $\times$ Seed Density & & ns & & ns & & ns & & ns & & ns \\
\hline
\end{tabular}

Kernel yield was significantly and positively related with nitrogen fertilization. However, differences were found to be related to N135, while no significant differences were found for N35 and N80. On the contrary, seeding density and sulfur treatment resulted not significantly affect final kernel yield. Results indicated 1000 kernel weight significantly decreasing as the seeding density increase from 90 to $180 \mathrm{~kg}$ seed ha ${ }^{-1}$. No difference (except those related to cultivars) was found for hectoliter weight. Kernel N was significantly increased by N135, while no significant differences were found for the other fertilization levels. Moreover, results also indicated a significant positive interaction between $\mathrm{S}$ and $\mathrm{N}$ fertilization in increasing the $\mathrm{N}$ accumulation in kernel. Kernel $\mathrm{C}$ content was found to be significantly decreased by the sulfur treatment (from $45.82 \% \pm 0.24 \%$ to $45.33 \% \pm 0.50 \%$ from S0 to S1). However, the decrease in $\mathrm{C}$ could not be considered important in terms of kernel quality.

These results were consistent with previous studies $[12,13,15]$ reporting nitrogen fertilization increasing the kernel yield. Further, other studies [15,36-38] reported a positive interaction between $\mathrm{N}$ and $\mathrm{S}$ fertilization in increasing kernel yield in wheat. Otteson et al. (2008) [14] found that $\mathrm{N}$ concentration in kernel being significantly increased by $\mathrm{N}$ fertilization, while being not significantly affected by seeding rate. Gooding et al. (2002) [12] and Zhang et al. (2016) [13] found a significant interaction between $\mathrm{N}$ fertilization and seeding density in determining the kernel yield.

A significant increase in kernel total protein content was due to nitrogen fertilization (Table 2). 
Table 2. Mean of kernel protein fraction results by nitrogen fertilization, sulfur fertilization, seed density, cultivar and first order interaction. The sig columns report the ANOVA results $\left(^{*}=0.05,{ }^{* *}=0.01,{ }^{* *}=0.001, \mathrm{~ns}=\right.$ not significant), while lowercase letters represent the Tukey HSD post hoc test results. RSE $=$ residual standard error.

\begin{tabular}{|c|c|c|c|c|c|c|c|c|c|c|c|c|c|c|}
\hline \multirow[t]{2}{*}{ Source of Variation } & \multicolumn{2}{|c|}{$\begin{array}{l}\text { Total Protein } \\
\text { (\%DW) }\end{array}$} & \multicolumn{2}{|c|}{$\begin{array}{c}\text { Insoluble Proteins } \\
\text { (\%DW) }\end{array}$} & \multicolumn{2}{|c|}{ Albumins (\%DW) } & \multicolumn{2}{|c|}{ Globuilins (\%DW) } & \multicolumn{2}{|c|}{ Gliadins (\%DW) } & \multicolumn{2}{|c|}{ Glutenins (\%DW) } & \multicolumn{2}{|c|}{$\begin{array}{l}\text { Total Gluten } \\
\text { (\%DW) }\end{array}$} \\
\hline & Average & sig & Average & sig & Average & sig & Average & sig & Average & sig & Average & sig & Average & sig \\
\hline \multicolumn{15}{|l|}{ Main effect } \\
\hline Andriolo & 12.41 & & 0.35 & & 1.97 & & 1.13 & & 3.92 & & 5.04 & & 8.96 & \\
\hline Sieve & 12.37 & & 0.36 & & 1.92 & & 1.10 & & 3.86 & & 5.13 & & 8.99 & \\
\hline Verna & 12.84 & & 0.37 & & 1.98 & & 1.16 & & 4.05 & & 5.28 & & 9.33 & \\
\hline Seeding density & & ns & & ns & & ns & & ns & & ns & & ns & & ns \\
\hline D90 & 12.18 & $\mathrm{a}$ & 0.35 & $\mathrm{a}$ & 1.94 & $\mathrm{a}$ & 1.12 & $\mathrm{a}$ & 3.90 & $\mathrm{a}$ & 5.05 & $\mathrm{a}$ & 8.95 & $\mathrm{a}$ \\
\hline D180 & 12.67 & a & 0.37 & $\mathrm{a}$ & 1.97 & a & 1.14 & a & 3.96 & $\mathrm{a}$ & 5.28 & $\mathrm{a}$ & 9.24 & a \\
\hline Sulfur & & ns & & $\mathrm{ns}$ & & ** & & ** & & * & & * & & ** \\
\hline So & 12.21 & $\mathrm{a}$ & 0.35 & $\mathrm{a}$ & 2.05 & $\mathrm{a}$ & 1.23 & $\mathrm{a}$ & 4.3 & $\mathrm{a}$ & 4.27 & $\mathrm{~b}$ & 8.57 & $\mathrm{~b}$ \\
\hline S1 & 12.86 & $\mathrm{a}$ & 0.36 & a & 1.86 & $\mathrm{~b}$ & 1.02 & $\mathrm{~b}$ & 3.55 & $\mathrm{~b}$ & 6.07 & $\mathrm{a}$ & 9.62 & a \\
\hline Nitrogen & & $* *$ & & * & & * & & ns & & $\mathrm{ns}$ & & ns & & * \\
\hline N35 & 11.7 & $\mathrm{~b}$ & 0.34 & $\mathrm{~b}$ & 1.81 & $\mathrm{~b}$ & 1.04 & $\mathrm{a}$ & 3.68 & $\mathrm{a}$ & 4.83 & $\mathrm{a}$ & 8.51 & $\mathrm{~b}$ \\
\hline N80 & 11.98 & $\mathrm{~b}$ & 0.35 & $\mathrm{~b}$ & 1.85 & $a b$ & 1.08 & a & 3.72 & $\mathrm{a}$ & 4.99 & a & 8.71 & $a b$ \\
\hline N135 & 13.93 & a & 0.4 & a & 2.2 & $\mathrm{a}$ & 1.28 & $\mathrm{a}$ & 4.38 & $\mathrm{a}$ & 5.68 & $\mathrm{a}$ & 10.06 & $\mathrm{a}$ \\
\hline RSE & 1.34 & & 0.03 & & 0.24 & & 0.31 & & 0.57 & & 0.63 & & 0.40 & \\
\hline \multicolumn{15}{|l|}{ Interactions } \\
\hline Nitrogen $\times$ Sulfur & & $*$ & & ns & & ns & & $\mathrm{ns}$ & & ns & & ns & & ns \\
\hline Nitrogen $\times$ Seed Density & & ns & & ns & & ns & & ns & & ns & & ns & & ns \\
\hline Sulfur $\times$ Seed Density & & ns & & ns & & ns & & $\mathrm{ns}$ & & ns & & ns & & ns \\
\hline
\end{tabular}


Moreover, significant differences were found between N135 level and the two lower levels, while no significant difference was found between N35 and N80. On the contrary, the adopted nitrogen fertilization levels had little effect on the protein composition of these old wheat varieties. Nitrogen fertilization significantly affected albumin content, which increased slightly (from $1.81 \%$ to $2.2 \%$ of DW), but only for the N135 treatment. Further, $\mathrm{N}$ fertilization significantly affected total gluten, which increased by about $18.2 \%$ from N35 to N135. In contrast, modern wheat varieties have been reported to be more sensitive to the amount of $\mathrm{N}$, expressed in both their yield potential and protein composition, while it appears to have little effect on albumins and globulins content $[39,40]$. It has also been reported to positively influence total gliadins and glutenin [41,42].

Results also indicated that the sulfur treatment deeply changed the protein composition. In particular, the sulfur treatment significantly decreased albumin, globulin and gliadin fractions, while it significantly increased glutenin (from $4.23 \%$ to $6.07 \%$ of DW). Moreover, also total gluten significantly increased by about $12.3 \%$ from S0 to S1. Previous studies have indicated that sulfur availability enhances the activity of enzymes such as nitrate reductase [43] and glutamine synthetase in flag leaves [44], thereby affecting the content of different protein components [45]. In particular, Tao et al., (2018) [18] reported that sulfur availability was positively correlated with glutenin production and negatively correlated with the ratio of gliadin to glutenin. To sum up the results of the impact of our factors on kernel proteins, nitrogen fertilization increased total protein and total gluten content, while the sulfur treatment changed the protein composition, increasing total gluten and glutenin, and decreasing other protein fractions.

Agronomical treatments affected dough rheology and, particularly, dough tenacity (P), dough extensibility (L), and deformation energy (W) (Table 3). On the other hand, the index of swelling (G) showed no significant difference. P increased slightly with sulfur and nitrogen fertilization. Dough extensibility was increased by nitrogen fertilization. Since dough deformation energy is the area under the tenacity and extensibility curve, both an increase in $\mathrm{P}$, and an increase in L increase $\mathrm{W}$. In fact, $\mathrm{W}$ increased by about $34 \%$ with nitrogen fertilization (from N35 to N135), compared to roughly $14 \%$ with the sulfur treatment. Increases due to the agronomical treatment are of particular interest for old wheat flours, especially when processed as Italian "Tipo 2" flours, as they are considered usually very weak in term of deformation energy [1], and any increase in this value has to be considered helpful for the breadmaking process.

Nitrogen fertilization increased the Verna W from 48 to $67 \times 10^{-4} \mathrm{~J}$, the Andriolo $\mathrm{W}$ from 49 to $54 \times 10^{-4} \mathrm{~J}$ and the Sieve $\mathrm{W}$ from 78 to $111 \times 10^{-4} \mathrm{~J}$. These values are consistent with alveograph evaluations in Migliorini et al. (2016) [5] for Verna and Sieve, while they are lower for Andriolo. Overall, $\mathrm{W}$ values remain low regardless of the agronomical treatment and, in fact, according to the common classification, flours with $\mathrm{W}$ below 90 are not considered suitable for breadmaking. In our study, Sieve, at nitrogen levels N80 and N135, exceeds this threshold and can be considered a weak flour. In this case, nitrogen fertilization was able to change the flour 'class'.

$\mathrm{W}$ values were compared to the literature with respect to total protein content [5] and their high molecular weight glutenin content [46]. Our data are consistent with earlier work, as both W and total proteins increased with nitrogen fertilization. Furthermore, a significant relationship between $\mathrm{W}$ and total protein was found $(p=0.008)$. Although we only have only data for total glutenin, a significant relationship between glutenin content and $\mathrm{W}$ was found $(p=0.02)$. In this case, both $\mathrm{W}$ and glutenin were found to be significantly affected by the $S$ treatment. This is consistent with an effect of $S$ fertilization on dough technological parameters reported in Tea et al. (2005) [16]. On the other hand, neither nitrogen nor sulfur were able to change the $\mathrm{P} / \mathrm{L}$ ratio. High $\mathrm{P} / \mathrm{L}$ is another limit of old wheat flours [8], but our data did not highlight any change due to the agronomical treatment. 
Table 3. Mean of alveograph results by nitrogen fertilization, sulfur fertilization, seed density, cultivar and first order interaction. The sig columns report the ANOVA results $\left({ }^{*}=0.05,{ }^{* *}=0.01,{ }^{* * *}=0.001, \mathrm{~ns}\right.$ $=$ not significant), while lowercase letters represent the Tukey HSD post hoc test results. RSE = residual standard error.

\begin{tabular}{|c|c|c|c|c|c|c|c|c|c|c|}
\hline \multirow{2}{*}{ Source of Variation } & \multicolumn{2}{|l|}{$\mathbf{W}$} & \multicolumn{2}{|l|}{$\mathbf{P}$} & \multicolumn{2}{|l|}{$\mathbf{L}$} & \multicolumn{2}{|c|}{$\mathrm{P} / \mathrm{L}$} & \multicolumn{2}{|l|}{ G } \\
\hline & Average & sig & Average & sig & Average & sig & Average & Sig & Average & Sig \\
\hline \multicolumn{11}{|l|}{ Main effect } \\
\hline Cultivar & & $* * *$ & & $* * *$ & & ns & & $* * *$ & & ns \\
\hline Andriolo & 52 & c & 33 & c & 44 & $\mathrm{a}$ & 0.85 & $\mathrm{c}$ & 14.5 & $\mathrm{a}$ \\
\hline Sieve & 94 & $\mathrm{a}$ & 57 & $\mathrm{a}$ & 40 & a & 1.53 & $\mathrm{a}$ & 13.9 & a \\
\hline Verna & 60 & $\mathrm{~b}$ & 40 & $\mathrm{~b}$ & 40 & $\mathrm{a}$ & 1.06 & $\mathrm{~b}$ & 13.0 & $\mathrm{a}$ \\
\hline Seeding density & & ns & & * & & ns & & ns & & ns \\
\hline D90 & 72 & $\mathrm{a}$ & 45 & a & 43 & $\mathrm{a}$ & 1.12 & $\mathrm{a}$ & 14.6 & $\mathrm{a}$ \\
\hline D180 & 65 & a & 42 & $\mathrm{~b}$ & 39 & $\mathrm{a}$ & 1.17 & $\mathrm{a}$ & 13.7 & $\mathrm{a}$ \\
\hline Sulfur & & $*$ & & * & & ns & & ns & & ns \\
\hline S0 & 64 & $\mathrm{~b}$ & 42 & $\mathrm{~b}$ & 39 & $\mathrm{a}$ & 1.14 & $\mathrm{a}$ & 13.7 & $\mathrm{a}$ \\
\hline S1 & 73 & a & 45 & a & 44 & a & 1.15 & a & 14.5 & a \\
\hline Nitrogen & & $* *$ & & * & & $*$ & & ns & & ns \\
\hline N35 & 58 & $\mathrm{~b}$ & 41 & $\mathrm{~b}$ & 36 & $\mathrm{~b}$ & 1.21 & $\mathrm{a}$ & 13.2 & $\mathrm{a}$ \\
\hline N80 & 69 & $a b$ & 44 & $\mathrm{ab}$ & 41 & $\mathrm{ab}$ & 1.1 & $\mathrm{a}$ & 14.2 & $\mathrm{a}$ \\
\hline N135 & 78 & $\mathrm{a}$ & 45 & $\mathrm{a}$ & 46 & $\mathrm{a}$ & 1.13 & a & 14.9 & a \\
\hline RSE & 11 & & 4 & & 10 & & 0.29 & & 1.7 & \\
\hline \multicolumn{11}{|l|}{ Interactions } \\
\hline Nitrogen $\times$ Sulfur & & ns & & ns & & ns & & ns & & \\
\hline $\begin{array}{c}\text { Nitrogen } \times \text { Seed } \\
\text { Density }\end{array}$ & & ns & & $*$ & & ns & & ns & & \\
\hline Sulfur $\times$ Seed Density & & ns & & ns & & ns & & ns & & \\
\hline
\end{tabular}

Our agronomical treatments did affect final bread quality (Table 4). Crumb density was significantly decreased by nitrogen fertilization. Crumb density is an important parameter for bread quality, since it can be considered a proxy for bread porosity. Nitrogen fertilization leads to higher protein content in kernel, higher $\mathrm{W}$ and, consequently, higher crumb density. Furthermore, nitrogen fertilization also affected crumb texture. Crumb springiness and crumb cohesiveness increased with nitrogen fertilization from N35 to N135 (by 17\% and 32\% respectively). Springiness describes how the crumb returns to its un-deformed state after a compression force is removed, while cohesiveness describes the amount of effort required to chew, and it is usually seen as a positive characteristic in baked products [47]. Nitrogen fertilization improved both these parameters, resulting in an improvement in bread crumb texture. The tested agronomical treatments, nitrogen and sulfur, significantly increased the total protein content of Italian "Tipo 2" flours; in particular, an enhancement of the storage proteins (i.e., gluten), was obtained. The effect of the agronomic treatments on the gluten proteins was different: nitrogen treatment equally increased glutenin and gliadin fractions, maintaining their ratio roughly unvaried; conversely, sulfur reduced the gliadins and enhanced the glutenins, determining a change in the proportion of the two components of the gluten. In the literature it is largely known that gluten plays a key role for the flour breadmaking performance, since it confers the dough unique visco-elastic properties [48-54]. Hence, sulfur and nitrogen treatments, impacting the gluten quantity, revealed that an agronomic practice could directly affect the most important actor in the breadmaking process [48-54]. This observation was well known for modern refined varieties, and could be extended to Italian "Tipo 2 " flours from old varieties. Rheological results showed a significant boost in the dough strength (W) as a consequence of both sulfur and nitrogen treatments. These results could be related to the higher gluten quantity of Italian "Tipo 2" flours, since in the literature it is largely known that gluten proteins significantly improve dough rheological/alveograph properties [48-54]. W represents an important parameter in the evaluation of the flour technological quality: the higher the $\mathrm{W}$ index, the higher the 
dough stability during mixing, gas holding capacity and performance during long fermentation time, since the alveographic test simulates the deformations occurring during the leavening and baking steps $[50,52]$. Furthermore, in the literature, $W$ values are commonly used to classify flours for their destination use $[50,52]$. With regard to the evaluation of bread quality, nitrogen treatment produced a significant decrease of bread crumb density, and a significant increase of texture parameters, namely springiness and cohesiveness. These results were consistent with data about the gluten content and alveographic parameters. Indeed, the increased gluten proteins and $\mathrm{W}$ value allowed a better gas retention capacity of the dough during the leavening and the baking. In detail, in the leavening, the gluten promotes a better retention of the gas produced during the yeast fermentation, allowing a better loaf increase; during baking, it allows the creation of a fine-even crumb while water evolves as vapor and gases further expand [50,52]. As a result, bread crumb appeared characterized by a significant lower density and by a porous structure. Moreover, TPA analysis showed that this crumb structure was characterized by a significant increase of springiness and cohesiveness. Both these texture parameters are associated to a better bread quality and are features largely appreciated by consumers [50,52]. Conversely, sulfur fertilization, although producing similar effects of nitrogen in term of W, did not significantly affect bread characteristics. This is probably linked to the observed decrease in the gliadin fraction [54]. The sulfur results highlight the importance of the ratio between gliadin and glutenins to obtain a bread with quality characteristics appreciated by consumers. Furthermore, it is important to point out that all the cited literature referred to breads made from refined flours, while these results allow to evaluate the effect of agronomical treatments on bread quality. Moreover, both chemical and rheological tests showed improvements in the Italian "Tipo 2" flour composition and dough rheology that not resulted in a significant improvement of the bread. Thus, the nitrogen fertilization could be useful to improve the poor technological features of weak flours. 
Table 4. Mean of quality analyses on breads shown by nitrogen fertilization, sulfur fertilization, seed density, cultivar and first order interaction. The sig columns report the ANOVA results $\left({ }^{*}=0.05,{ }^{* *}=0.01,{ }^{* * *}=0.001, \mathrm{~ns}=\right.$ not significant), while lowercase letters represent the Tukey HSD post hoc test results. RSE $=$ residual standard error

\begin{tabular}{|c|c|c|c|c|c|c|c|c|c|c|c|c|}
\hline \multirow{2}{*}{ Source of Variation } & \multicolumn{2}{|c|}{ Volume (mL) } & \multicolumn{2}{|c|}{ Crumb Density $\left(\mathrm{g} \mathrm{mL}^{-1}\right)$} & \multicolumn{2}{|c|}{ Hardness (N) } & \multicolumn{2}{|c|}{ Springiness (mm) } & \multicolumn{2}{|c|}{ Cohesiveness } & \multicolumn{2}{|c|}{ Chewiness $(\mathrm{N} \cdot \mathrm{mm})$} \\
\hline & Average & sig & Average & sig & Average & sig & Average & sig & Average & sig & Average & sig \\
\hline \multicolumn{13}{|l|}{ Main effect } \\
\hline Cultivar & & $* * *$ & & ns & & ns & & ns & & ns & & ns \\
\hline Andriolo & 1043 & $\mathrm{~b}$ & 1.42 & $\mathrm{a}$ & 11.7 & $\mathrm{a}$ & 0.74 & $\mathrm{a}$ & 0.32 & $\mathrm{a}$ & 2.57 & $\mathrm{a}$ \\
\hline Sieve & 1165 & a & 1.24 & $\mathrm{a}$ & 7.3 & a & 0.81 & a & 0.41 & $\mathrm{a}$ & 2.44 & a \\
\hline Verna & 993 & c & 1.36 & $\mathrm{a}$ & 8.6 & $\mathrm{a}$ & 0.75 & $\mathrm{a}$ & 0.39 & $\mathrm{a}$ & 2.34 & $\mathrm{a}$ \\
\hline Seeding density & & ns & & ns & & ns & & ns & & ns & & ns \\
\hline D90 & 1052 & $\mathrm{a}$ & 1.26 & $\mathrm{a}$ & 8.3 & $\mathrm{a}$ & 0.80 & $\mathrm{a}$ & 0.39 & $\mathrm{a}$ & 2.51 & $\mathrm{a}$ \\
\hline D180 & 1082 & $\mathrm{a}$ & 1.42 & $\mathrm{a}$ & 10.2 & $\mathrm{a}$ & 0.74 & a & 0.36 & $\mathrm{a}$ & 2.39 & $\mathrm{a}$ \\
\hline Sulfur & & ns & & ns & & ns & & ns & & ns & & ns \\
\hline SO & 1079 & $\mathrm{a}$ & 1.31 & $\mathrm{a}$ & 10.2 & $\mathrm{a}$ & 0.78 & $\mathrm{a}$ & 0.39 & $\mathrm{a}$ & 2.35 & $\mathrm{a}$ \\
\hline S1 & 1054 & $\mathrm{a}$ & 1.37 & $\mathrm{a}$ & 8.3 & $\mathrm{a}$ & 0.76 & $\mathrm{a}$ & 0.37 & $\mathrm{a}$ & 2.55 & $\mathrm{a}$ \\
\hline Nitrogen & & ns & & * & & ns & & $*$ & & * & & ns \\
\hline N35 & 1039 & $\mathrm{a}$ & 1.50 & a & 11.4 & $\mathrm{a}$ & 0.70 & a & 0.31 & $\mathrm{a}$ & 2.29 & $\mathrm{a}$ \\
\hline N80 & 1077 & $\mathrm{a}$ & 1.29 & $\mathrm{~b}$ & 7.4 & $\mathrm{a}$ & 0.79 & $\mathrm{~b}$ & 0.41 & $\mathrm{~b}$ & 2.21 & $\mathrm{a}$ \\
\hline N135 & 1085 & $\mathrm{a}$ & 1.23 & $\mathrm{~b}$ & 8.9 & a & 0.82 & $\mathrm{~b}$ & 0.41 & $\mathrm{~b}$ & 2.85 & $\mathrm{a}$ \\
\hline RSE & 57 & & 0.26 & & 4.7 & & 0.10 & & 0.09 & & 0.95 & \\
\hline \multicolumn{13}{|l|}{ Interactions } \\
\hline Nitrogen $\times$ Sulfur & & ns & & ns & & ns & & ns & & ns & & ns \\
\hline Nitrogen $\times$ Seed 1 & nsity & ns & & ns & & ns & & ns & & ns & & ns \\
\hline Sulfur $\times$ Seed Density & & ns & & ns & & ns & & ns & & ns & & ns \\
\hline
\end{tabular}




\section{Conclusions}

The aim of the study was to evaluate whether the poor technological bread-making qualities of three old wheat flours could be improved with an agronomical treatment. Thus, we tested the effect of nitrogen fertilization, sulfur fertilization and seed density on kernel composition, dough rheology and bread quality.

Results related to seed density were minor and cannot be used to improve the breadmaking properties of the tested varieties. Sulfur fertilization was found to affect protein composition and, particularly, increase gluten content. W values consistently increased with sulfur addition. Since W is a key parameter in the assessment of flour workability, a sulfur foliar application in such weak flour could be a promising strategy to improve their technological performance. However, further studies on a broad range of varieties, with in-depth chemical analyses are still required to fully understand the effect. Finally, nitrogen fertilization was found to be a useful tool to modulate the assessed qualitative parameters as it was able to increase yield, total protein and total gluten content, and protein composition. Furthermore, nitrogen fertilization improved the $\mathrm{W}$ value of the dough, and changed bread crumb density and texture. Hence, $\mathrm{N}$ fertilization can be successfully used to improve technological parameters of the tested weak flours.

In conclusion, the poor performance of these flours can be improved with agronomical treatments designed to obtain higher-quality bread. These results can be considered of particular interest for old wheats with poor technological performance. However, more work is needed in order to make further improvements to their processability. Moreover, additional trials including more years and different pedo-climatic conditions are required to evaluate the interaction between cultivars and the agronomical treatments.

Author Contributions: Conceptualization, L.G., M.N. and M.M.; data curation, L.G., M.N. and M.M.; formal analysis, L.G. and M.N.; funding acquisition, M.M., A.P. and S.O.; investigation, L.G., M.N., M.M., P.M., and A.C.; methodology, M.N. and M.M.; project administration, M.M.; supervision, A.P. and S.O.; validation, L.G. and M.N.; writing-original draft, L.G. and M.N. All authors have read and agreed to the published version of the manuscript.

Funding: The project was part of the Measure 16.2 "GRANT GRani Antichi Nuove Tecniche di coltivazione", founded by the 2014-2020 Rural Development Programme for Tuscany.

Acknowledgments: The authors want to thank Az. Agric. Chiarion Giuseppe e Francesco, Consorzio Agrario di Siena and Cassa di Risparmio di Firenze. A special thank is also given to Roberto Vivoli from DAGRI for his technical support during the whole experimentation.

Conflicts of Interest: The authors declare no conflict of interest.

\section{References}

1. Ghiselli, L.; Rossi, E.; Whittaker, A.; Dinelli, G.; Baglio, A.P.; Andrenelli, L.; Benedettelli, S. Nutritional characteristics of ancient Tuscan varieties of Triticum aestivum L. Ital. J. Agron. 2016, 11, 237-245. [CrossRef]

2. Guerrini, L.; Parenti, O.; Angeloni, G.; Zanoni, B. The bread making process of ancient wheat: A semi-structured interview to bakers. J. Cereal Sci. 2019, 87, 9-17. [CrossRef]

3. Sanchez-Garcia, M.; Álvaro, F.; Peremarti, A.; Martín-Sánchez, J.A.; Royo, C. Changes in bread-making quality attributes of bread wheat varieties cultivated in Spain during the 20th century. Eur. J. Agron. 2015, 63, 79-88. [CrossRef]

4. Finney, K.F.; Barmore, M.A. Loaf volume and protein content of hard winter and spring wheats. Cereal Chem. 1948, 25, 291-312.

5. Migliorini, P.; Spagnolo, S.; Torri, L.; Arnoulet, M.; Lazzerini, G.; Ceccarelli, S. Agronomic and quality characteristics of old, modern and mixture wheat varieties and landraces for organic bread chain in diverse environments of northern Italy. Eur. J. Agron. 2016, 79, 131-141. [CrossRef]

6. Decreto del Presidente della Repubblica. Available online: https://www.fircislfocus.it/knowledgebase/dprdecreto-del-presidente-della-repubblica-definizione (accessed on 11 December 2019).

7. Dinu, M.; Whittaker, A.; Pagliai, G.; Benedettelli, S.; Sofi, F. Ancient wheat species and human health: Biochemical and clinical implications. J. Nutr. Biochem. 2018, 52, 1-9. [CrossRef] 
8. Cappelli, A.; Cini, E.; Guerrini, L.; Masella, P.; Angeloni, G.; Parenti, A. Predictive models of the rheological properties and optimal water content in doughs: An application to ancient grain flours with different degrees of refining. J. Cereal Sci. 2018, 83, 229-235. [CrossRef]

9. Sahi, S.S.; Little, K.; Ananingsih, V.K. Quality control. In Bakery products science and technology; John Wiley \& Sons, Ltd.: Chichester, UK, 2014; pp. 489-509.

10. Parenti, A.; Guerrini, L.; Granchi, L.; Venturi, M.; Benedettelli, S.; Nistri, F. Control of mixing step in the bread production with weak wheat flour and sourdough. J. Agric. Eng. 2013, 44-48. [CrossRef]

11. Geleta, B.; Atak, M.; Baenziger, P.S.; Nelson, L.A.; Baltenesperger, D.D.; Eskridge, K.M.; Shipman, M.J.; Shelton, D.R. Seeding rate and genotype effect on agronomic performance and end-use quality of winter wheat. Crop Sci. 2002, 42, 827-832.

12. Gooding, M.J.; Pinyosinwat, A.; Ellis, R.H. Responses of wheat grain yield and quality to seed rate. J. Agric. Sci. 2002, 138, 317-331. [CrossRef]

13. Zhang, Y.; Dai, X.; Jia, D.; Li, H.; Wang, Y.; Li, C.; Xu, H.; He, M. Effects of plant density on grain yield, protein size distribution, and breadmaking quality of winter wheat grown under two nitrogen fertilisation rates. Eur. J. Agron. 2016, 73, 1-10. [CrossRef]

14. Otteson, B.N.; Mergoum, M.; Ransom, J.K. Seeding rate and nitrogen management on milling and baking quality of hard red spring wheat genotypes. Crop Sci. 2008, 48, 749-755. [CrossRef]

15. Salvagiotti, F.; Castellarín, J.M.; Miralles, D.J.; Pedrol, H.M. Sulfur fertilization improves nitrogen use efficiency in wheat by increasing nitrogen uptake. F. Crop. Res. 2009, 113, 170-177. [CrossRef]

16. Tea, I.; Genter, T.; Violleau, F.; Kleiber, D. Changes in the glutathione thiol-disulfide status in wheat grain by foliar sulfur fertilization: Consequences for the rheological properties of dough. J. Cereal Sci. 2005, 41, 305-315. [CrossRef]

17. Tea, I.; Genter, T.; Naulet, N.; Lummerzheim, M.; Kleiber, D. Interaction between nitrogen and sulfur by foliar application and its effects on flour bread-making quality. J. Sci. Food Agric. 2007, 87, 2853-2859. [CrossRef]

18. Tao, Z.; Chang, X.; Wang, D.; Wang, Y.; Ma, S.; Yang, Y.; Zhao, G. Effects of sulfur fertilization and short-term high temperature on wheat grain production and wheat flour proteins. Crop J. 2018, 6, 413-425. [CrossRef]

19. Fabbri, C.; Napoli, M.; Mancini, M.; Brandani, G.; Vivoli, R.; Orlandini, S. Adopting precision agriculture to improve the cultivation of old wheat varieties in Tuscany (Italy). In Proceedings of the Precision Agriculture 2019-Papers Presented at the 12th European Conference on Precision Agriculture, Wageningen, The Netherlands, 8-11 July 2019; pp. 461-467.

20. Cereals-Determination of Bulk Density, Called Mass per Hectolitre-Part 1: Reference Method. 2009. Available online: https://www.iso.org/standard/44524.html (accessed on 11 December 2019).

21. ISO 520 Cereals and Pulses-Determination of the Mass of 1000 Grains. 2010. Available online: https://www.iso.org/standard/52270.html (accessed on 11 December 2019).

22. Žilić, S.; Barać, M.; Pešić, M.; Dodig, D.; Ignjatović-Micić, D. Characterization of proteins from grain of different bread and durum wheat genotypes. Int. J. Mol. Sci. 2011, 12, 5878-5894. [CrossRef]

23. Osborne, T.B. The Proteins of the Wheat Kernel; Science: Washington, DC, USA, 1907.

24. Ju, Z.Y.; Hettiarachchy, N.S.; Rath, N. Extraction, denaturation and hydrophobic properties of rice flour proteins. J. Food Sci. 2001, 66, 229-232. [CrossRef]

25. Afify, A.E.-M.M.R.; El-Beltagi, H.S.; Abd El-Salam, S.M.; Omran, A.A. Protein Solubility, Digestibility and Fractionation after Germination of Sorghum Varieties. PLoS ONE 2012, 7, e31154. [CrossRef]

26. Lookhart, G.; Bean, S. Separation and characterization of wheat protein fractions by high-performance capillary electrophoresis 1 . Cereal Chem. 1995, 72, 527-532.

27. Okada, K.; Negisi, Y.; Nagao, S. Characterization of acetic acid-soluble and insoluble proteins isolated from doughs mixed in the presence of N-ethylmaleimide. Cereal Chem. 1988, 65, 248-252.

28. Tecson, E.M.S.; Esmama, B.V.; Lontok, L.P.; Juliano, B.O. Cereal chemistry. Cereal Chem. 1971, 48, $168-181$.

29. Bean, S.R.; Lyne, R.K.; Tilley, K.A.; Chung, O.K.; Lookhart, G.L. A rapid method for quantitation of insoluble polymeric proteins in flour. Cereal Chem. J. 1998, 75, 374-379. [CrossRef]

30. ICC Standard 167 Determination of Crude Protein in Grain and Grain Products for Food and Feed by the Dumas Combustion Principle. 2000. Available online: http://old.icc.or.at/standard_methods/167 (accessed on 11 December 2019). 
31. ISO 27971 Cereals and cereal products-Common wheat (Triticum aestivum L.) -Determination of Alveograph Properties of Dough at Constant Hydration from Commercial or Test Flours and Test Milling Methodology. 2015. Available online: https://www.iso.org/standard/63535.html (accessed on 11 December 2019).

32. Parenti, O.; Guerrini, L.; Canuti, V.; Angeloni, G.; Masella, P.; Zanoni, B. The effect of the addition of gelatinized flour on dough rheology and quality of bread made from brown wheat flour. LWT 2019, 106, 240-246. [CrossRef]

33. Ali, O.A.M.; Mohammed, A.S.H. AACC Approved Methods ofthe AACC, 10th Edition 2000. Agric. Sci. 2019, $6,550-570$.

34. Cappelli, A.; Guerrini, L.; Parenti, A.; Palladino, G.; Cini, E. Effects of wheat tempering and stone rotational speed on particle size, dough rheology and bread characteristics for a stone-milled weak flour. J. Cereal Sci. 2020, 91, 1-7. [CrossRef]

35. Kim, S.; Kwak, H.S.; Jeong, Y. Effect of water roux starter (Tangzhong) on texture and consumer acceptance of rice pan bread. J. Texture Stud. 2017, 48, 39-46. [CrossRef]

36. Salvagiotti, F.; Miralles, D.J. Radiation interception, biomass production and grain yield as affected by the interaction of nitrogen and sulfur fertilization in wheat. Eur. J. Agron. 2008, 28, 282-290. [CrossRef]

37. Randall, P.J.; Spencer, K.; Freney, J.R. Sulfur and nitrogen fertilizer effects on wheat. I. Concentrations of sulfur and nitrogen and the nitrogen to sulfur ratio in grain, in relation to the yield response. Aust. J. Agric. Res. 1981, 32, 203-212. [CrossRef]

38. Randall, P.J.; Freney, J.R.; Smith, C.J.; Moss, H.J.; Wrigley, C.W.; Galbally, I.E. Effect of Additions of Nitrogen and Sulfur to Irrigated Wheat at Heading on Grain Yield, Composition and Milling and Baking Quality. Aust. J. Exp. Agric. 1990, 30, 95-101. [CrossRef]

39. Fuertes-Mendizábal, T.; Aizpurua, A.; González-Moro, M.B.; Estavillo, J.M. Improving wheat breadmaking quality by splitting the $\mathrm{N}$ fertilizer rate. Eur. J. Agron. 2010, 33, 52-61. [CrossRef]

40. Pedersen, L.; Jørgensen, J.R. Variation in rheological properties of gluten from three biscuit wheat cultivars in relation to nitrogen fertilisation. J. Cereal Sci. 2007, 46, 132-138. [CrossRef]

41. Johansson, E.; Prieto-Linde, M.L.; Svensson, G. Influence of nitrogen application rate and timing on grain protein composition and gluten strength in Swedish wheat cultivars. J. Plant Nutr. Soil Sci. 2004, 167, 345-350. [CrossRef]

42. Luo, C.; Branlard, G.; Griffin, W.; McNeil, D. The effect of nitrogen and sulfur fertilisation and their interaction with genotype on wheat glutenins and quality parameters. J. Cereal Sci. 2000, 31, 185-194. [CrossRef]

43. Swamy, U.; Wang, M.; Tripathy, J.N.; Kim, S.-K.; Hirasawa, M.; Knaff, D.B.; Allen, J.P. Structure of spinach nitrite reductase: Implications for multi-electron reactions by the iron-sulfur:Siroheme cofactor. Biochem. 2005, 44, 16054-16063. [CrossRef]

44. Geng, J.; Ma, Q.; Chen, J.; Zhang, M.; Li, C.; Yang, Y.; Yang, X.; Zhang, W.; Liu, Z. Effects of polymer coated urea and sulfur fertilization on yield, nitrogen use efficiency and leaf senescence of cotton. F. Crop. Res. 2016, 187, 87-95. [CrossRef]

45. Wrigley, C.W.; Du Cros, D.L.; Fullington, J.G.; Kasarda, D.D. Changes in polypeptide composition and grain quality due to sulfur deficiency in wheat. J. Cereal Sci. 1984, 2, 15-24. [CrossRef]

46. Branlard, G.; Dardevet, M. Diversity of grain protein and bread wheat quality: II. Correlation between high molecular weight subunits of glutenin and flour quality characteristics. J. Cereal Sci. 1985, 3, 345-354. [CrossRef]

47. Young, L.S. Applications of texture analysis to dough and bread; Elsevier: Amsterdam, The Netherlands, 2012; pp. 562-579.

48. Veraverbeke, W.S.; Delcour, J.A. Wheat protein composition and properties of wheat glutenin in relation to breadmaking functionality. Crit. Rev. Food Sci. Nutr. 2002, 42, 179-208.

49. Shewry, P.R.; Halford, N.G.; Tatham, A.S.; Popineau, Y.; Lafiandra, D.; Belton, P.S. The high molecular weight subunits of wheat glutenin and their role in determining wheat processing properties. Adv. Food Nutr. Res. 2003, 45, 219-302.

50. Pagani, M.A.; Marti, A.; Bottega, G. Wheat Milling and Flour Quality Evaluation. In Bakery Products Science and Technology; Zhou, W., Hui, Y.H., De Leyn, I., Pagani, M.A., Rosell, C.M., Selman, J.D., Therdthai, N., Eds.; John Wiley \& Sons, Ltd.: Chichester, UK, 2014.

51. Wieser, H. Chemistry of gluten proteins. Food Microbiol. 2007, 24, 115-119. [CrossRef] [PubMed] 
52. Cauvain, S.P. Bread-The Product. In Technology of Breadmaking; Springer US: Boston, MA, USA, 2014; pp. 1-19.

53. Delcour, J.A.; Joye, I.J.; Pareyt, B.; Wilderjans, E.; Brijs, K.; Lagrain, B. Wheat Gluten Functionality as a Quality Determinant in Cereal-Based Food Products. Annu. Rev. Food Sci. Technol. 2012, 3, 469-492. [CrossRef] [PubMed]

54. Barak, S.; Mudgil, D.; Khatkar, B.S. Relationship of gliadin and glutenin proteins with dough rheology, flour pasting and bread making performance of wheat varieties. LWT_Food Sci. Technol. 2013, 51, 211-217. [CrossRef]

(C) 2020 by the authors. Licensee MDPI, Basel, Switzerland. This article is an open access article distributed under the terms and conditions of the Creative Commons Attribution (CC BY) license (http://creativecommons.org/licenses/by/4.0/). 